\title{
EXPERIMENTAL ELECTRIC VEHICLE EŠUS GEN2
}

\section{JOSEF BŘOUŠEK, MARTIN BUKVIC, PAVEL JANDURA}

Technical University of Liberec, Studentská 2, CZ 46117 Liberec, Czech Republic, Department of Vehicles and Engines, Mechanical Engineering Faculty; Institute for Nanomaterials, Advanced Technologies and Innovation

E-mail: josef.brousek@tul.cz

\section{SHRNUTÍ}

V úvodu článku je popsán vznik a koncepce experimentálního elektromobilu. Následuje popis použitých mechanických a elektrických komponent v kombinaci s konstrukčními řešeními dílčích celků jako je např. pohonné ústrojí vozidla nebo trakční baterie vozidla. Volba použitých komponent a konstrukčních řešení je zde zhodnocena vzhledem k současným trendům ve vývoji elektromobilů. Článek obsahuje i simulace dynamiky vozidla pro vybrané elektromotory se kterými se počítalo pro zástavbu do vozidla.

KLIČCOÁ SLOVA: ELEKTROMOBILITA, HNACI ÚSTROJII, TRAKČNII ELEKTROMOTOR, PŘEVODOVKA, LITHIOVÉ AKUMULÁTORY

\section{ABSTRACT}

In the introduction to the article, the conception and development of an experimental electric vehicle is described. It is followed by a description of the used mechanical and electrical components in combination with the design solutions of sub-units, such as the vehicle powertrain and traction battery. The choice of components and design solutions is evaluated here with regard to the current trends in the development of battery electric vehicles.

KEYWORDS: ELECTRIC MOBILITY, POWERTRAIN, TRACTION ELECTRIC MOTOR, TRANSMISSION, LITHIUM BATTERIES

\section{INTRODUCTION}

In 2011, the Institute of Mechatronics and Computer Engineering established ties with the Department for Vehicles and Engines, both part of Technical University of Liberec, with the aim of expanding the competencies of both entities in the field of electric mobility. In the same year, a project was drafted to develop a light experimental BEV category vehicle. This vehicle now serves as an open platform for educational purposes and the testing of existing and currently developed components designed for electric vehicles. These include, in particular, the design and implementation of an electric powertrain and the design of the traction battery and its management coupled with the other on-board electronics.

\section{CONCEPTION OF THE VEHICLE}

Conceptually, it is a four-wheeled two-seat vehicle of the Roadster type chassis with a solid frame and front wheel drive (FWD) see Fig. 1. The frame design is mixed. It is a combination of a steel weldment and an assembly bolted from extruded aluminum profiles [1].

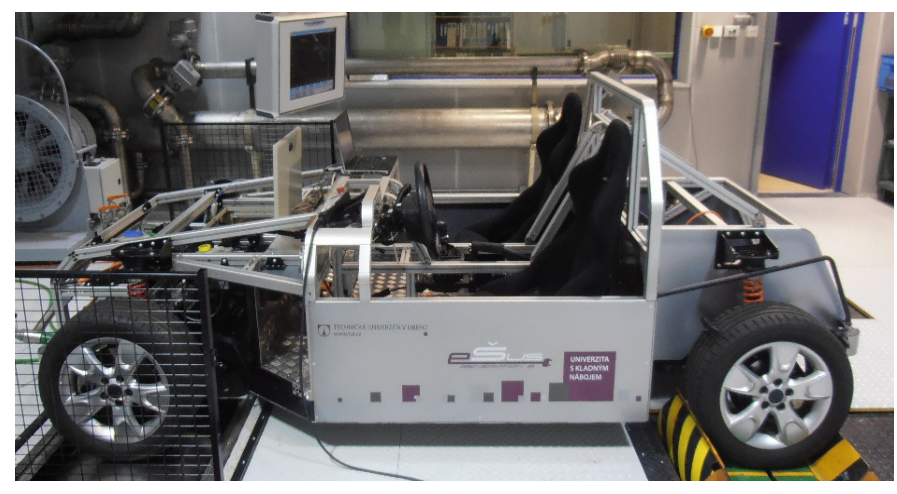

FIGURE 1: Experimental electric vehicle eŠus Gen2.

OBRÁZEK 1: Experimentální elektromobil eŠus Gen2.

The wheelbase is $2462 \mathrm{~mm}$. Wheel track of both axles is identical at $1435 \mathrm{~mm}$ due to the specific use of a pair of front axles from the Skoda Fabia with McPherson suspension. This solution opens up the possibility of future installation of a system for steering the rear axle. In the current version, the control of the rear axle is mechanically locked. Vehicle height is $1300 \mathrm{~mm}$ and its length is $3350 \mathrm{~mm}$. Curb weight of the vehicle incl. traction battery is $850 \mathrm{~kg}$. 
In the space between the axles, the perimeter steel frame forms a shaft designed for installation of the battery box with traction battery and the BMS. This concept can dedicate most space for the traction battery while preserving the spatial comfort of the cabin and luggage compartment. Its main drawback is the necessity of a higher seating position for the crew due to the minimum design height of the battery. This ranges from about $100 \mathrm{~mm}$ with Tesla Model S/X vehicles up to about $160 \mathrm{~mm}$ with the BMW i3 vehicle. For the eŠus Gen2 experimental vehicle, the construction height of the battery is $84 \mathrm{~mm}$.

\section{PROTOTYPE OF THE DUAL MOTOR DRIVE SYSTEM POWERTRAIN}

The main requirement of any powertrain concept is to achieve the maximum efficiency under all operating conditions. However, with the most common powertrain concept (one motor with SST) this requirement is hard to achieve in particular when there is high demand for vehicle driving dynamics or a wide range of driving speeds. This leads to the situation where one high power motor works at a fraction of its nominal power for the most of its operational time. This imposes high demands on the motor design in terms of its overall efficiency. There are several powertrain configurations [2][3] that due to more or less complicated technical solutions, offer significant improvement in this area of interest.

One of these is a powertrain configuration known as the Dual Motor Drive System (DMDS). The main idea of operation is based on the joint control of torque of both powertrain motors primary and assistant. The DMDS control algorithm can engage just the primary motor, which in most cases is designed for maximum effectiveness at low loads when the assistant motor is freewheeling. The assistant motor is automatically engaged by the control algorithm only under specified conditions and can thus be optimized for heavy load operation or better efficiency at high driving speed. The DMDS therefore optimizes the efficiency of the powertrain for most operating conditions.

One of technology advantages of DMDS as opposed to powertrains with multi-speed transmission (MST) [4], [5], [6], is the seamless torque distribution to the wheels, which is problematic even with dual clutch transmission. Also, the ability to achieve a better weight distribution of the vehicle mass and the cooling efficiency of individual components while preserving the compact design should be considered.

Several versions of the DMDS concept can be implemented, but the most promising characteristics of DMDS are offered in AWD configuration using a combination of two sets of electric motors with its own singe-speed transmission (SST), installed at both axles. Then, the SSTs can also utilize different gear ratios. This particular DMDS configuration is used by Tesla powertrains [7].
They use two different asynchronous motors (ACIM) with the same gear ratio of $i=9.7$ in both SSTs.

The only fundamental requirement for an assistance motor is that it must generate the smallest possible losses in its magnetic circuit when freewheeling. From this perspective, the ACIM type seems to be the best suited. In this mode of operation its relatively narrow band of high efficiency is not a great deficiency when compared with PMSM. Based on the above characteristics, it can be said that DMDS and its latest modification with three motors (two motors with electronic differential for torque vectoring on the rear axle, one motor with SST on the front axle) currently ranks among the most promising concepts of powertrains for BEV.

We have decided to verify the real world characteristics of DMDS in the second generation of the experimental electric vehicle. Our prototype of DMDS anticipates the use of two electric motors mounted on both sides of a common shaft of one SST in FWD configuration. The main reasons for this particular design is to test the common behavior of two motors on the same shaft in the joint torque control. Another important reason was the significant production cost of our SST design. However, the principle of operation remains the same.

\subsection{REQUIREMENTS FOR DRIVING DYNAMICS}

The DMDS device type provides an improvement in the overall efficiency in comparison with the powertrain with SST, primarily assuming a requirement for higher driving dynamics of the vehicle. For this reason, the powertrain of the Gen2 vehicle was designed to achieve an acceleration of $0-100 \mathrm{~km} \cdot \mathrm{h}^{-1}$ in under $10 \mathrm{~s}$. This value may be still considered as a borderline for vehicles with better driving dynamics. The maximum speed of the designed powertrain is $100 \mathrm{~km} \cdot \mathrm{h}^{-1}$. This value has been chosen to enable real world testing of the vehicle acceleration rate. The Gen2 vehicle platform was never intended for use on the road, so the maximum speed and vehicle behavior at higher speeds was not a subject of interest. To meet this requirement, due to the design curb weight of $850 \mathrm{~kg}$, it is necessary to have a peak mechanical output of the powertrain of over $70 \mathrm{~kW}$.

\subsection{THE CHOICE OF ELECTRIC TRACTION MOTORS}

To optimize the DMDS concept for maximum efficiency it is necessary to differentiate the performance of both motors, usually in a ratio of $1: 2$ up to $1: 3$. The main machine should be able to operate continuously while driving over the entire range of constant speeds while exhibiting an efficiency of over $80 \%$. For an up-to-date BEV M1 category with a curb weight of $1500 \mathrm{~kg}$, this corresponds to a permanent performance of 25-30 kW. For the Gen2 vehicle, the requirement for permanent performance was calculated to a value of $10 \mathrm{~kW}$ with the ability 
of short term overload to $20 \mathrm{~kW}$. Thus, the assistance motor must have a peak power of min. $50 \mathrm{~kW}$. As the main motor we decided on the ME 1302 type, liquid-cooled AF-PMSM from Motenergy, Inc. As an assistance motor it was originally proposed to use the ACIM principle, AC-34 type from HPEVS. However, during development we were forced to change the type of assistant motor. This change during development was due primarily to the limited budget allocated for this project. We used a custom modified version of an RF-PMSM motor originally developed by the Zero Motorcycles company, Type 75-7. An important benefit was the availability of configuration files for Sevcon Gen4 series FOC controllers which we decided to use. The main drawback of using this kind of "low-cost" motor is that in most cases there are no detailed technical data and efficiency maps available. However, this is not a crucial issue for verifying the fundamental characteristics of the DMDS concept.

\subsection{SINGLE-SPEED TRANSMISSION DESIGN}

From the parameters of traction motors for the DMDS device are derived the basic requirements for the parameters of the SST. Designed maximum input torque is $200 \mathrm{Nm}$ and maximum operating speed is $8000 \mathrm{rpm}$. The overall gear ratio $\mathrm{lc}<9$ for the maximum vehicle speed of $100 \mathrm{~km} . \mathrm{h}^{-1}$.

Due to the vehicle concept, it was decided to design the SST prototype in the form of a diploma thesis. For this design, components from the MQ 200 02T manual six-speed MST were taken. The input shaft was designed and manufactured for the aforementioned connection of both electric motors. The adjustment of the standard input shaft also included installation of the parking pawl wheel. The countershaft was also modified from a standard one, by shortening and adjusting the diameters. The differential was left as a standard one, but because of the shortening of the resultant depth of the SST, it is rotated by $180^{\circ}$ compared to its original location in the MQ 200. The

TABLE 1: Main parameters of DMDS electric traction motors. TABULKA 1: Hlavní parametry trakčních motorů pro DMDS.

\begin{tabular}{lllll} 
Motor Parameter & Unit & $\begin{array}{l}\text { Motenergy } \\
\text { ME1302 }\end{array}$ & $\begin{array}{l}\text { HPEVS } \\
\text { AC-34 }\end{array}$ & $\begin{array}{l}\text { Zero Motorcycles } \\
\text { ZF 75-7 }\end{array}$ \\
\hline Motor Type & {$[-]$} & AF-PMSM & ACIM & RF-PMSM \\
\hline Peak Torque & {$[\mathrm{N} . \mathrm{m}]$} & 50 & 144 & 144 \\
\hline Cont. Torque & {$[\mathrm{N} . \mathrm{m}]$} & 12 & 12 & 45 \\
\hline Peak Power & {$[\mathrm{kW}]$} & 17 & 55 & 50 \\
\hline Cont. Power & {$[\mathrm{kW}]$} & 4 & 4 & 17 \\
\hline Max. Speed & {$[\mathrm{rpm}]$} & 8000 & 8000 & $6000^{*}$ \\
\hline Max. Efficiency & {$[-]$} & 0.92 & 0.88 & 0.92 \\
\hline Weight & {$[\mathrm{kg}]$} & 15.9 & 38.5 & 17
\end{tabular}

* The lower max. speed of the ZF 75-7 motor means it is necessary to use a third gear of the MQ200 $02 T$ transmission to reach the speed of $100 \mathrm{~km} \cdot \mathrm{h}^{-1}$

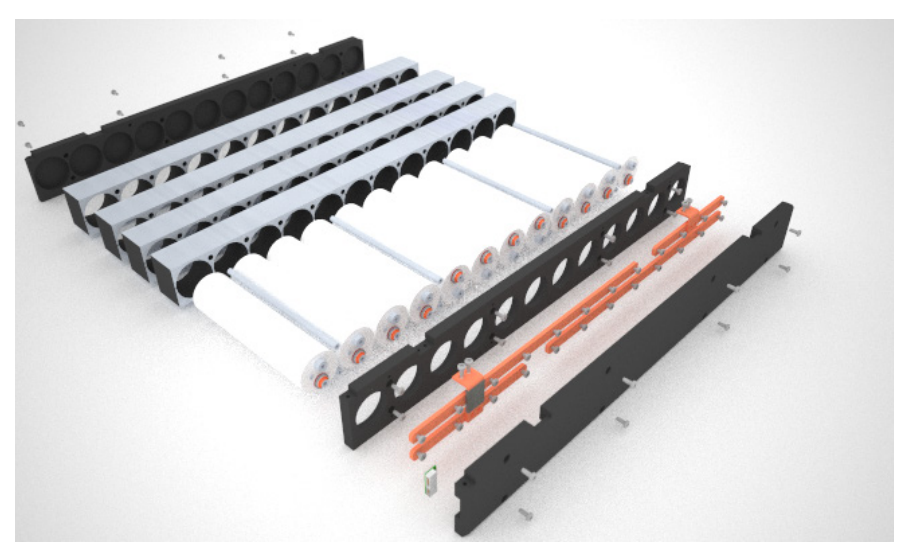

FIGURE 2: from the left: Motenergy ME 1302, HPEVS AC-34, Zero Motorcycles ZF 75-7.

OBRÁZEK 2: zleva: Motenergy ME 1302, HPEVS AC-34, Zero Motorcycles ZF 75-7.

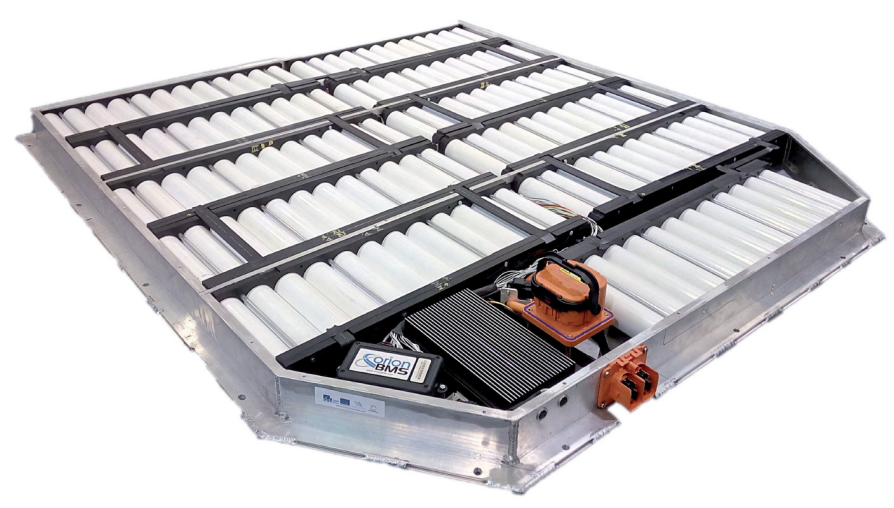

FIGURE 3: Model of internal layout of the DMDS transmission. OBRÁZEK 3: Model vnitřního uspořádání DMDS převodovky.

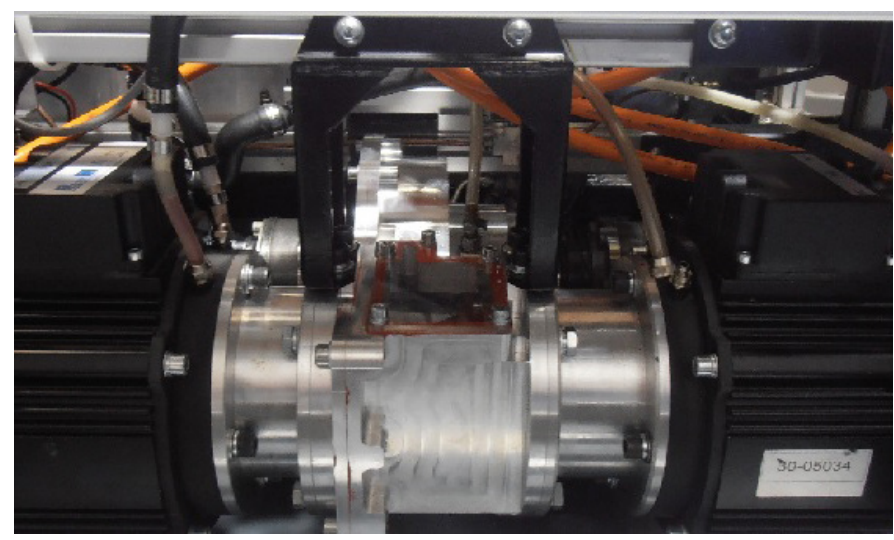

FIGURE 4: The final model of the DMDS powertrain. OBRÁZEK 4: Výsledný model hnacího ústrojí DMDS.

resulting gear is formed by tooth wheels of the second gear and differential constant gear with a gear number of ic $=8.9$. The proposed SST allows service exchangeable gears in the range of second, third and fourth gear from the MQ 200 02T.

On both sides of the input shaft, joints are designed with tight springs for connecting the electric motors by means of fixed couplings. 
The SST housing is made from aluminum alloy. Since it is a prototype, manufacturing using chip machining on a CNC milling machine was chosen. The shapes of the SST housing were then subjected to this technology. The housing was designed with regard to low weight and sufficient stiffness of the construction. Given the requirement for mutual alignment, the lid (cover) and the housing are secured with respect to one another with precise pins. Material for manufacture of the prototype housing is EN AW 7021 [AlZn5.5Mg1.5]. This material exhibits low internal stress, excellent dimensional stability, strength and also very good machinability. For oil filling and draining, there are formed two holes with plugs with threads on the SST. The weight of the housing including flanges for connecting electric motors is $8 \mathrm{~kg}$. The complete SST including fillings weighs $22 \mathrm{~kg}$.

The parking pawl system prevents starting (drive away) of the vehicle, even when handbrake is unloaded. The base plate of the pawl (latch) is designed for manufacture by milling on a CNC machine from the same material as the SST housing.

The pawl is mechanically operated by a Bowden cable in the Gen2 vehicle, which is based on the original VW Group DSG transmission selector lever.

The parking pawl is produced from 11523 non-alloyed steel. Other parts are taken from the VW Group DQ series transmission.

\subsection{CONNECTING THE ELECTRIC MOTORS TO THE}

\section{TRANSMISSION AND FITTING THE POWERTRAIN TO THE VEHICLE}

Both types of electric motor have a standard NEMA C-face flange and a grooved output shaft. To connect them to the SST housing, flanges from the same material as the housing were designed. Steel couplings are used for connection to the SST driving shaft. The DMDS is positioned in the vehicle in front of the front axle. Here it is hung behind the SST housing, both on an extruded profile, which is resiliently mounted in silent blocks, and furthermore it is flexibly clamped in the axle housing of the front axle.

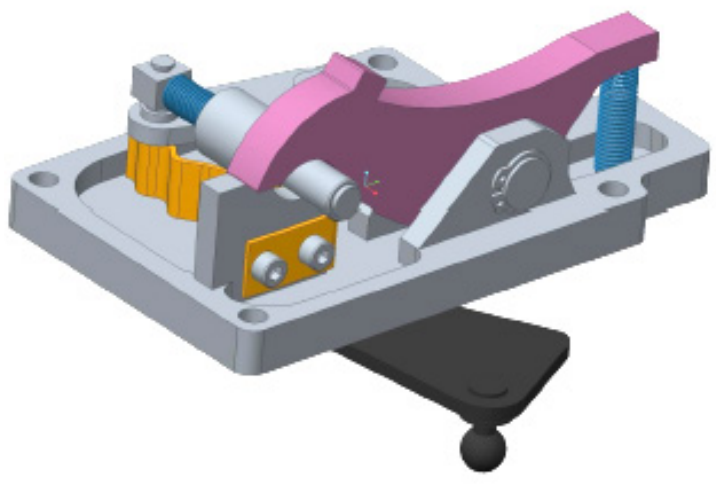

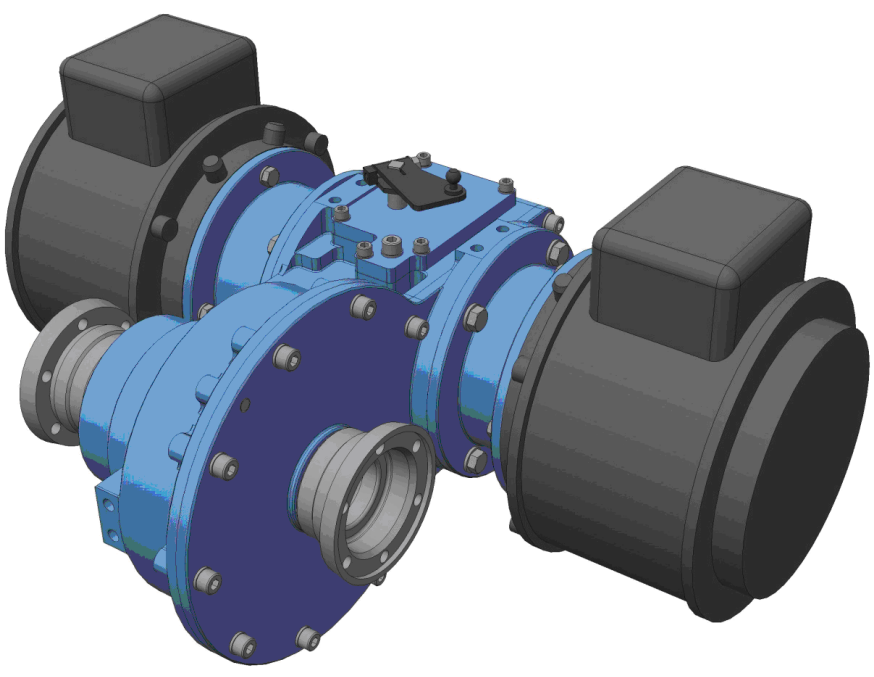

FIGURE 6: Detail of the DMDS installation in the vehicle. OBRÁZEK 6: Detail instalace DMDS ve voze.

\section{DESCRIPTION OF THE TRACTION BATTERY BOX DESIGN AND THE BMS}

The battery box was designed as an aluminum welding with two reinforcing bars. The box is inserted into a shaft formed by a peripheral steel frame which is bolted to the lower rim of the box. This solution could be further developed in the form of an automatic exchange system for the battery box.

Requirements for traction batteries on current M1 category BEVs are mostly met using Li-lon cell technologies with NCA-C(Si) and NMC $-\mathrm{C}(\mathrm{Si})$ chemical structures. In addition to the chemical structure, the format of the cell and its size also significantly affects its specific energy density. The small cylindrical format 18650 cells exhibit the highest specific energy density in the last decade. Cells in other formats, whether prismatic, cylindrical or pouch embodiment, exhibit significantly worse specific energy density.

Modules of the Gen2 traction battery are designed for Saft VL $41 \mathrm{M}$ cylindrical cells of the NCA-C type. These large format (144 Wh) cells were preferred to the small ones $(\sim 12 \mathrm{Wh})$ of

FIGURE 5: Parking pawl mechanism.

OBRÁZEK 5: Mechanismus parkovací západky.

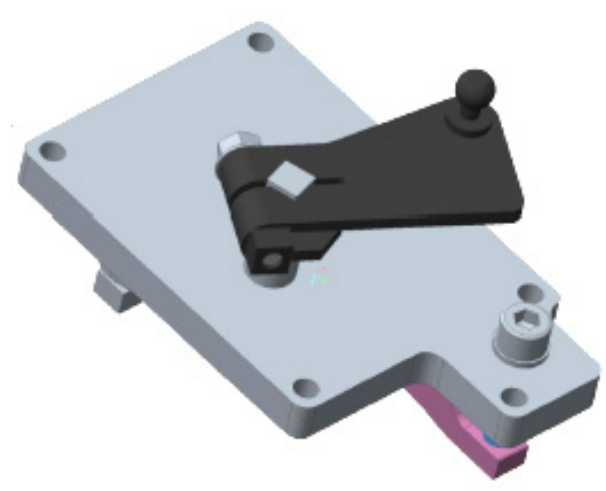




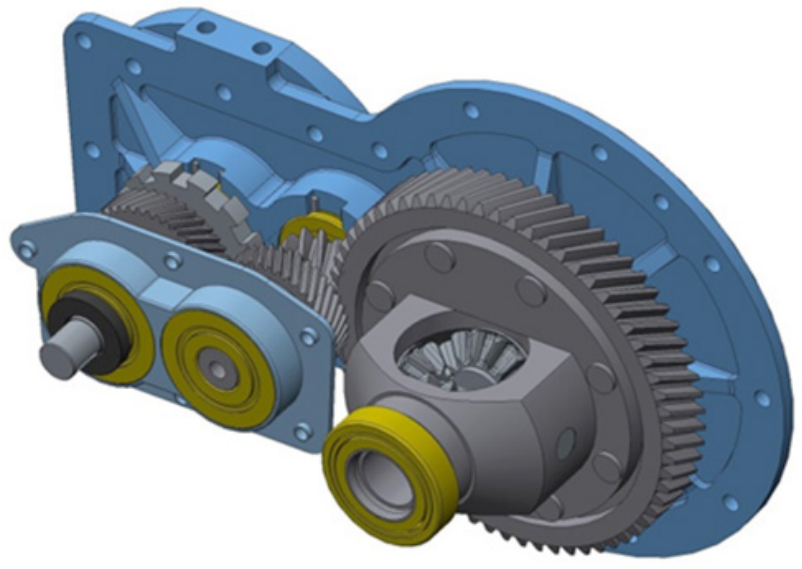

FIGURE 7: Functional sample of the Gen2 vehicle traction battery. OBRÁZEK 7: Funkční vzorek trakční baterie vozu Gen2.

the 18650 format, mainly due to easier installation. For the next generation of traction battery, we already take into account a transition to the 18650 format or the newly introduced 20700 and 21700 formats.

The designed battery box enables the setting up of modules with cells in two basic versions.

The first one enables installation of 11 battery modules with an energy of $18.8 \mathrm{kWh}$, but without active thermal management.

The second one uses thermal management for peak load of the 6C / 960A battery. Then the box is set up with 10 modules with an energy of only $17.2 \mathrm{kWh}$.

Each module consists of 12 cells in the $3 s 4 p$ wiring, see Fig. 8 . Cells are positioned between two faces from flame retardant plastic. Cell terminals are interconnected flat $\mathrm{Cu}$ busbars with a cross-section of $70 \mathrm{~mm}^{2}$ and then covered with a plastic lid. One $10 \mathrm{k}$ thermistor is attached to each four cells. Their outlets together with the wires for sensing the cell voltage are connected to a common connector for connecting the module with the BMS.
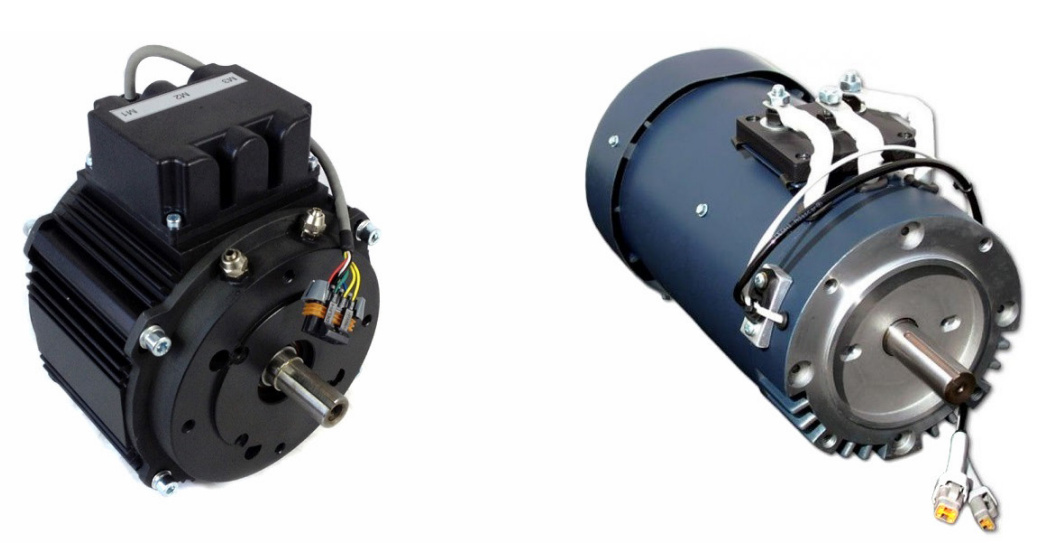

FIGURE 8: Model of disassembled module of Gen2 traction battery. OBRÁZEK 8: Model rozloženého modulu trakční baterie Gen2.
Thermal management was designed using the properties of the PCM material [8] to instantly transform heat from the cells to a change of its phase. This principle is extended to a system of distribution plates (sheets) that facilitate the rapid transfer of heat from the PCM to the exchanger in the battery box base. Thus, it is hybrid management. In the traction battery prototype, this system has not been set up yet.

The electronic BMS system of the vehicle comes from Ewert Energy Systems, Inc. It is a centralized system with a main unit. Balancing cell current is $100 \mathrm{~mA}$.

\section{CHARGING SYSTEM OF THE VEHICLE}

The charging system of the Gen2 vehicle is implemented using three one phase on-board chargers, each with an output (power) of $2.3 \mathrm{~kW}$. If there is a three-phase socket, it can be charged with a power up to $7 \mathrm{~kW}$ and the vehicle can thus be fully recharged in 3 hours. The vehicle is equipped with the European standardized charging plug according to IEC 62196, also known as "Mennekes". The BMS allows charging of the traction battery by recuperative braking.

\section{CONCLUSION}

At the beginning, given the considerable complexity of the issues as a whole, we have chosen a DMDS with the same type of electric motors, namely with the ME 1302 type. Currently, there is an ongoing optimization of the setting of the inverters for master-slave operation of both motors on a common shaft to achieve the maximum possible parameters declared by the manufacturers. This optimization is evaluated by means of measurements on a chassis dynamometer at this time, see Fig. 9. After the successful optimization of the master-slave operation we are planning to implement the fundamental parts of the DMDS control algorithm, still with the ME 1302 motors. In the future after evaluating the real-world characteristic we would like to implement an advanced DMDS control algorithm with two different motors.

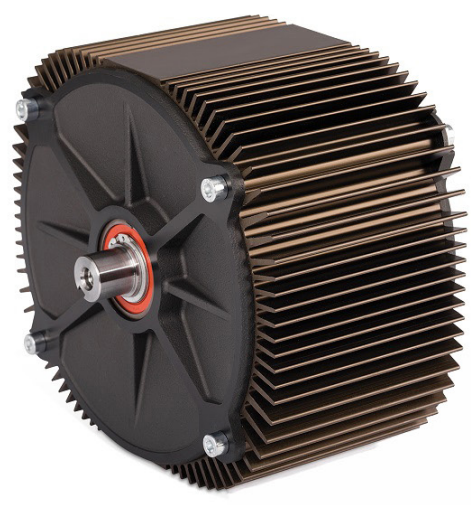




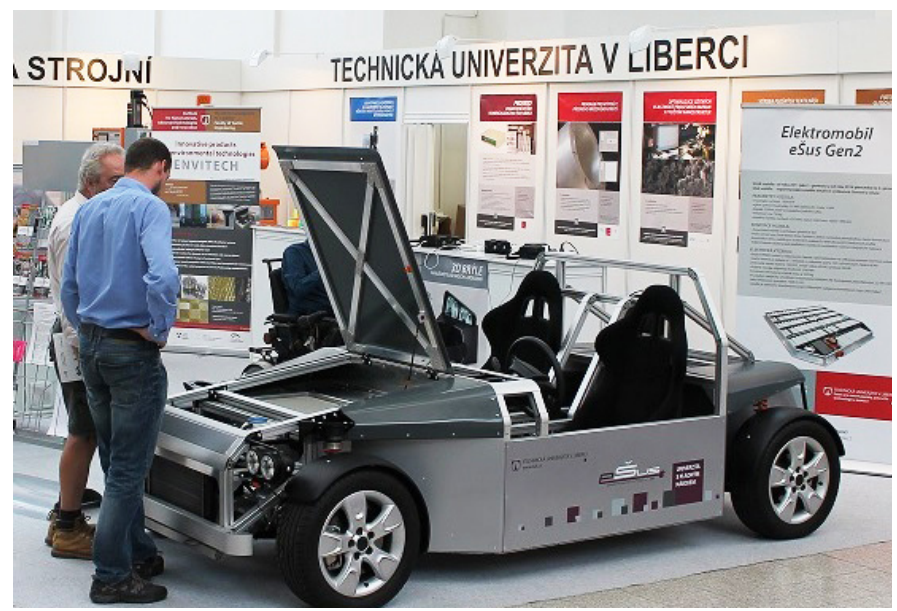

FIGURE 9: Experimental vehicle eŠus Gen2 on a chassis dynamometer. OBRÁZEK 9: Experimentální elektromobil eŠus Gen2 na válcové brzdě.

\section{ACKNOWLEDGEMENTS}

This publication was written at the Technical University of Liberec as part of the project 21127 with the support of the Specific University Research Grant, as provided by the Ministry of Education, Youth and Sports of the Czech Republic in the year 2016.

The results of this project L01201 were obtained through the financial support of the Ministry of Education, Youth and Sports in the framework of the targeted support of the "National Programme for Sustainability I" and the OPR\&DI project Centre for Nanomaterials, Advanced Technologies and Innovation CZ.1.05/2.1.00/01.0005.

\section{LIST OF ABBREVIATIONS}

$\begin{array}{ll}\text { ACIM } & \text { Alternating Current Induction Motor } \\ \text { AF- } & \text { Axial Flux Electric Machine } \\ \text { BEV } & \text { Battery Electric Vehicle } \\ \text { BMS } & \text { Battery Management System } \\ \text { DCT } & \text { Dual Clutch Transmission } \\ \text { DMDS } & \text { Dual Motor Drive System } \\ \text { Li-lon } & \text { Lithium - lon technology } \\ \text { MST } & \text { Multi - Speed Transmission } \\ \text { NCA } & \text { Nickel Cobalt Aluminum } \\ \text { NEDC } & \text { New European Driving Cycle } \\ \text { NMC } & \text { Nickel Manganese Cobalt } \\ \text { PCM } & \text { Phase Change Material } \\ \text { PMSM } & \text { Permanent Magnet Synchronous Machine } \\ \text { RF- } & \text { Radial Flux Electric Machine } \\ \text { SST } & \text { Single - Speed Transmission } \\ \text { AWD } & \text { All Wheel Drive }\end{array}$

\section{REFERENCES}

[1] Jandura, P., Bukvic, M.: Lightweight Battery Electric Vehicle for Educational Purposes. In: Applied Mechanics and Materials Vol. 390 (2013) pp. 281-285. ICMAE 2013, Moscow.

[2] Ehsani, M., GAO Y., EMADI, A. Configurations of EVs In: Modern electric, hybrid electric, and fuel cell vehicles: fundamentals, theory, and design. $2^{\text {nd }}$ ed. Boca Raton: CRC Press, c2010, xxii, 534 p. Power electronics and applications series. ISBN 14-200-5398-1.

[3] Felden, M., Butterling, P., Jeck, P., Eckstein, L., Hameyer, K. Electric vehicle drive trains: From the specification sheet to the drive-train concept. In: Proceedings of $14^{\text {th }}$ International Power Electronics and Motion Control Conference EPEPEMC 2010. DOI: 10.1109/EPEPEMC.2010.5606531.

[4] TANG, Y. Tesla Motors, Inc. "Dual Motor Drive and Control System for an Electric Vehicle". U.S. Patent 20100222953.

[5] Ren, Q., Crolla, D.A., Morris, A. Effect of transmission design on Electric Vehicle (EV) performance. In: 2009 IEEE Vehicle Power and Propulsion Conference. IEEE, 2009, pp. 1260-1265. DOI: 10.1109/VPPC.2009.5289707.

[6] Viotto, F. A Novel Seamless 2-Speed Transmission System for Electric Vehicles: Principles and Simulation Results. In: Electronic Systems for Vehicle Propulsion Symposium. Troy (Detroit), MI, 8-9 November 2011.

[7] Holdstock, T., Sorniotti, A., Everitt M., Fracchia M., Bologna, S., BERTOLOTTO, S. Energy consumption analysis of a novel four-speed dual motor drivetrain for electric vehicles. In: 2012 IEEE Vehicle Power and Propulsion Conference. IEEE, 2012, pp. 295-300. DOI: 10.1109/ VPPC.2012.6422721.

[8] AllCell Technologies, LLC. PCC Thermal Management Material. Chicago, USA, 2014. 